\title{
Abattoir-based study on the epidemiology of caprine tuberculosis in Ethiopia using conventional and molecular tools
}

\author{
Benti Deresa ${ }^{1,2,3}$, Franz J Conraths ${ }^{3,4}$ and Gobena Ameni ${ }^{\text {* }}$
}

\begin{abstract}
Background: Despite the important role of goats for meat and milk production in Ethiopia, little information is available on the epidemiology of caprine tuberculosis (TB). Caprine TB is important as milk is usually consumed raw particularly by Ethiopian pastoralists. The objectives of the present study were to estimate the prevalence of TB in goats at an abattoir, to evaluate associated risk factors and to characterize the causative mycobacteria.

Methods: A cross-sectional study was conducted on 1990 randomly selected male goats that were slaughtered at Luna Export Abattoir of central Ethiopia. Postmortem examination, mycobacterial culturing and molecular typing techniques like genus typing, deletion typing and spoligotyping were used.

Result: The overall prevalence of caprine TB-like lesions was 3.5\%. The lesion prevalence increased significantly with increasing age. Mycobacteria were found by culture and seen as acid fast bacilli in 12\% of the goats with TB-like lesions. Characterization of the eight isolates using multiplex polymerase chain reaction (PCR) indicated that five of them belonged to the genus Mycobacterium. Four of the latter were confirmed to be members of the $M$. tuberculosis complex. Further characterization of the three M. tuberculosis isolates by spoligotyping identified them as type SIT53 and two new spoligotypes.
\end{abstract}

Conclusion: The isolation of $M$. tuberculosis from goats in this study indicates a potential risk of transmission of $M$. tuberculosis between humans and goats.

Keywords: Goat, Tuberculosis, Epidemiology, Molecular typing, Mycobacterium tuberculosis, Ethiopia

\section{Background}

Caprine tuberculosis (TB) caused mainly by Mycobacterium bovis and $M$. caprae [1,2] poses a risk to goat health and production in developing world [3-5]. Recently, reports of caprine TB have increased in several countries; even in those practicing a long standing test and slaughter policy $[2,3,5-10]$. It is reported that the infection is widespread in Africa where goats co-graze with cattle that are not subject to TB testing and slaughter regimes [9-11]. Goats may become infected with $M$. bovis when sharing pastures with infected cattle, at watering points, market places and shared night shelters [6].

\footnotetext{
*Correspondence: gobenachimdi2009@yahoo.co.uk

'Aklilu Lemma Institute of Pathobiology, Addis Ababa University, PO Box 1176, Addis, Ethiopia

Full list of author information is available at the end of the article
}

In Ethiopia, mixed farming of cattle and goats is a common practice. Livestock move freely from one region to another and from farm-to-farm. Thus, this practice poses a high risk of inter- and intraspecies transmission and spread of M. bovis infection [12]. This mixed farming of small and large ruminants is especially a risk to goats in countries like Ethiopia where bovine TB is endemic [13] and reports have shown a prevalence of bovine $\mathrm{TB}$ ranging from $3.4 \%$ in small holder production systems to $50 \%$ in intensive dairy production systems [14-17].

A previous study [18] reported a prevalence of $4.2 \% \mathrm{~TB}$ in Ethiopian goats and also reported the occurrence of the disease for the first time in Ethiopia. However, that study did not identify the species of the M. tuberculosis complex (MTBC). Thus, there is little information on the status and etiology of caprine TB in Ethiopia. As scientific knowledge is required to design appropriate control methods,

\section{Biomed Central}


this study was performed to estimate the prevalence of caprine TB in slaughter goats, evaluate associated risk factors, and characterize the causative agents.

\section{Materials and methods Study site and animals}

This study was conducted in Luna Modern Export Abattoir at Modjo Town, which is located $73 \mathrm{~km}$ southeast of Addis Ababa in central Ethiopia. The abattoir is privately owned and primarily male goats are slaughtered for export purpose.

All goats were of local breeds and originated mainly from Arsi, Borana, Jimma, Somali and South Wello representing different agro-ecological zones. All goats had been kept under extensive production systems either as mixed crop-livestock production system or as a pastoral system of production. Goats were purchased at different local markets and transported to the abattoir. At the abattoir, animals were fed, watered, and rested for 24 to 72 hrs before being slaughtered. The TB status of the goats was not known as there was no pre-slaughter tuberculin skin testing scheme.

\section{Study design and sampling techniques}

A cross-sectional study design was used. The design involved stratification of the goats according to geographic origin and goat type to estimate the prevalence of caprine TB and assess the potential risk factors of the disease. The goat type was defined according to its origin and the physical description given earlier [4]. The study goats were also categorized into two age groups conventionally: $\leq 1.5$ years as young, and $>1.5$ years as adult on the basis of the dentition as described earlier for African indigenous goats [19].

The selection of the goats was based on systematic random sampling while the goats were moving in line to the slaughter hall. The selected goats were identified using permanent marker, kept separately after selection and released for slaughter one after the other. The sampling interval was obtained by dividing the total number of animals slaughtered from specific geographical origin within specific day by the estimated daily sample size [20]. Twelve goats were sampled during every study day. Thus, the total number of animal slaughtered in the particular day from a particular origin was divided by twelve and every $\mathrm{N}^{\text {th }}$ animal was selected after random selection of the first animal until the daily sample size was met. Accordingly, a total of 1990 goats were examined.

\section{Postmortem examination}

Postmortem inspection was performed following a procedure described previously [21]. All pulmonary lobes and the lymph nodes of the head (retropharyngeal, mandibular), thorax (mediastinal and bronchial), mesenterium, and liver were examined thoroughly. The carcass including internal organs and lymph nodes were examined under a bright-light source.

The lung and the lymph nodes were cut into approximately $2 \mathrm{~cm}$ thick slices to facilitate the detection of lesions using separate sterile scalpel blades. The cut surfaces were examined visually under bright light for the presence of lesions compatible with TB [22,23]. Gross nodular lesions of caseous necrosis and/or calcification were considered as suspected for TB. Such tissues were collected for bacteriological culture into sterile universal bottles with $5 \mathrm{ml}$ of $0.9 \%$ saline solution. The samples were transported to Aklilu Lemma Institute of Pathobiology (ALIPB) on the same day and stored at +2 to $+8^{\circ} \mathrm{C}$ for a maximum of one month until mycobacteriological culturing was carried out. However, almost all samples were cultured within a few days of sampling.

\section{Culturing and identification of mycobacteria}

Specimen processing and culturing for mycobacteria was carried out at TB laboratory of ALIPB in accordance with the guidelines of the Office des Internationale Epizooties [24]. In the laboratory, individual tissue specimens were sectioned using sterile blades in sterile Petri dishes to obtain fine pieces and then homogenized with a mortar and pestle. The homogenate was decontaminated using $2 \mathrm{ml}$ of $4 \% \mathrm{NaOH}$ for $15 \mathrm{~min}$ and then centrifuged at 3,000 rpm for $15 \mathrm{~min}$. The supernatant was discarded and the sediment was neutralized by $1 \%(0.1 \mathrm{~N}) \mathrm{HCl}$ using phenol red as indicator. Neutralisation was considered to be achieved when the color of the solution was changed from purple to yellow.

Thereafter, $0.1 \mathrm{ml}$ of the suspension was inoculated onto a duplicate set of Löwenstein-Jensen (LJ) slants; one supplemented with $0.4 \%$ sodium pyruvate (LJ pyruvate) and the other with glycerol (standard LJ). Cultures were incubated aerobically at $37^{\circ} \mathrm{C}$ for at least eight weeks with weekly observation for growth according to [25]. Positive cultures were confirmed by Ziehl-Neelsen staining and heat killed in water bath at $80^{\circ} \mathrm{C}$ for $45 \mathrm{~min}$. The heat killed isolates was stored at $-20^{\circ} \mathrm{C}$ for further molecular typing.

\section{Mycobacterial genus typing}

Mycobacterial genus typing was done using polymerase chain reaction (PCR), which differentiates the MTBC from the $M$. avium complex, $M$. intracellularae and other mycobacterial species. PCR was conducted as described previously [26]. Heat killed Ziehl-Neelsen positive samples were used as source of the DNA template. DNA amplifications were done in a thermocycler with $20 \mu \mathrm{l}$ reaction volume consisting: $5 \mu \mathrm{l}$ of heat killed cells as a template, $8 \mu$ l HotstarTaqMasterMix (MgCL2, dNTP, Taq polymerase and PCR buffer) (Qiagen, United Kingdom) for each sample, $0.3 \mu \mathrm{l}$ of each of the six 
Table 1 Primers used for genus and RD9 typing of isolated mycobacteria

\begin{tabular}{|c|c|c|}
\hline Primer name & Primer sequence $\left(5^{\prime}\right.$ to $\left.3^{\prime}\right)$ & Product size \\
\hline MYCGEN-F & AGAGTTTGATCCTGGCTCAG & $1030 \mathrm{bp}$ \\
\hline MYCGEN-R & TGCACACAGGCCACAAGGGA & \\
\hline MYCAV-R & ACCAGAAGACATGCGTCTTG & $180 \mathrm{bp}$ \\
\hline MYCINT-F & CCTITAGGCGCATGATGTCTITA & $850 \mathrm{bp}$ \\
\hline TB1-F & GAACAATCCGGAGTTGACAA & $372 \mathrm{bp}$ \\
\hline TB-R & AGCACGCTGTCAATCATGTA & \\
\hline RD9_IntR & CTGGACCTCGATGACCACTC & $\begin{array}{l}396 \mathrm{bp} \\
\text { (presence of RD9) }\end{array}$ \\
\hline RD9_FlankF & AACACGGTCACGTTGTCGTG & $\begin{array}{l}575 \mathrm{bp} \\
\text { (absence of RD9) }\end{array}$ \\
\hline RD9_FlankR & CAAACCAGCAGCTGTCGTTG & \\
\hline
\end{tabular}

primer per sample and $5.2 \mu \mathrm{l}$ of Qiagen water per sample. The name and nucleotide sequence of each primer used for amplification in genus typing is given in Table 1.

M. tuberculosis strains (H37Rv) and M. avium were used as positive controls while Qiagen water was used as negative control. The reaction mixture was then heated in a Programme Thermal Controller (Applied Biosystem; PTC- $100^{\mathrm{TM}}$ ) using the following amplification programs: $95^{\circ} \mathrm{C}$ for $10 \mathrm{~min}$ for enzyme activation; $95^{\circ} \mathrm{C}$ for $1 \mathrm{~min}$ for denaturation; $61^{\circ} \mathrm{C}$ for $0.5 \mathrm{~min}$ for annealing; $72^{\circ} \mathrm{C}$ for $2 \mathrm{~min}$ for extension; involving 35 cycles all in all and final extension at $72^{\circ} \mathrm{C}$ for $10 \mathrm{~min}$.

A $1.5 \%$ agarose gel was prepared and the products were electrophoresed in $10 \times \mathrm{TAE}$ running buffer. Ethidium bromide at ratio of 1:10, 100 bp DNA ladder, and orange 6x loading dye were used in gel electrophoresis. Finally, bands were visualized using alpha innotech, version 1.2.0.1 (Alpha Innotech Corporation) in a multi-image ${ }^{\mathrm{TM}}$ light cabinet.

\section{Region of difference (RD) deletion typing}

For deletion typing, the procedure described earlier [16] was followed. The RD9 deletion typing was carried out on isolates that showed band for $M$. tuberculosis complex by genus typing. Each sample was tested in a separate PCR tube. Primers directed against the RD9 were used to generate a deletion profile that would allow species identification of the isolate.

RD9 is a 2030 base pair (bp) gene segment of $M$. tuberculosis and PCR analysis using flanking primers revealed that RD9 is absent in M. bovis, M. microti, and $M$. africanum [27]. Primers used for RD9 typing and the size of PCR product size expected in the presence or absence of the respective region of difference is given in Table 1 .

The reaction mixture consisted of: $10 \mu \mathrm{l}$ of HotStarTaq master mix, $0.3 \mu \mathrm{l} \times 3$ of each primer (flank_R, F and Int) of the respective deletion typing, $2 \mu \mathrm{l}$ DNA template and $7.1 \mu \mathrm{l}$ Qiagen water to a final volume of $20 \mu \mathrm{l}$. M. tuberculosis $\mathrm{H} 37 \mathrm{Rv}$ and M. bovis 2122/97 were used as positive controls while Qiagen water was used as negative control. The mixture was heated in a Programme Thermal Controller (Applied Biosystem; PTC- $100^{\mathrm{TM}}$ ) using an initial hot start of $95^{\circ} \mathrm{C}$ for 15 min followed by 35 cycles of $95^{\circ} \mathrm{C}$ for $1 \mathrm{~min}$; $55^{\circ} \mathrm{C}$ for $1 \mathrm{~min}$; and $72^{\circ} \mathrm{C}$ for $1 \mathrm{~min}$; a final extension step of $72^{\circ} \mathrm{C}$ for $10 \mathrm{~min}$ to complete the cycle. PCR products were electrophoresed in $1.5 \%$ agarose gel in $10 \times$ TAE running buffer. Ethidium bromide at ratio of

Table 2 Individual variables, prevalence, and univariate analysis of risk factor of tuberculosis-like lesions in slaughtered goats

\begin{tabular}{|c|c|c|c|c|}
\hline Variables & No of carcasses examined & No (\% positive) & $x^{2}$-value & $P$-value \\
\hline Age & & & 6.436 & $0.011^{*}$ \\
\hline$\leq 1.5$ year & 1048 & $26(2.5)$ & & \\
\hline$>1.5$ year & 942 & $43(4.6)$ & & \\
\hline Origin & & & 6.140 & $0.189^{*}$ \\
\hline Borena & 472 & $23(4.9)$ & & \\
\hline Arsi & 360 & $13(3.6)$ & & \\
\hline Jimma & 386 & $15(3.9)$ & & \\
\hline South wello & 386 & $10(2.6)$ & & \\
\hline Somali & 386 & $8(2.1)$ & & \\
\hline Goat type & & & 1.165 & 0.76 (NS) \\
\hline Somali & 858 & $31(4.5)$ & & \\
\hline Arsi-Bale & 360 & $13(3.6)$ & & \\
\hline C. Lowlands & 386 & $15(3.9)$ & & \\
\hline Afar & 386 & $10(2.6)$ & & \\
\hline
\end{tabular}

*-the value is significant; NS- not significant. 
Table 3 Multivariate analysis of risk factor with presence of tuberculosis-like lesions in goats

\begin{tabular}{|c|c|c|c|c|}
\hline Variable & No. of carcasses examined & OR & $P$-value & $95 \% \mathrm{Cl}$ \\
\hline \multicolumn{5}{|l|}{ Age of goat } \\
\hline$\leq 1.5$ year & 1048 & 1 & 1 & \\
\hline$>1.5$ year & 942 & 1.88 & $0.013^{*}$ & $1.142-3.096$ \\
\hline \multicolumn{5}{|c|}{ Origin of goat } \\
\hline Somali & 386 & 1 & 1 & \\
\hline Borena & 472 & 2.14 & $0.034^{*}$ & $1.068-5.473$ \\
\hline Arsi & 360 & 1.83 & 0.187 (NS) & $0.746-4.462$ \\
\hline Jimma & 386 & 1.78 & 0.196 (NS) & $0.744-4.258$ \\
\hline South Wello & 386 & 1.24 & 0.65 (NS) & $0.485-3.187$ \\
\hline
\end{tabular}

*-the value is significant; NS- not significant.

1:10,100 bp DNA ladder and orange $6 \times$ loading dye (Gene Craft, Germany) were used in electrophoresis. Finally, bands were visualized using alpha innotech, version 1.2.0.1 (Alpha Innotech Corporation) in a multi-image ${ }^{\mathrm{TM}}$ light cabinet.

\section{Spoligotyping}

Spoligotyping was performed at ALIPB; following the procedure described earlier [28] and according to the spoligotype kit supplier's instructions (Ocimum Biosolutions Company, lisselstein, The Netherlands). The direct repeat (DR) region were amplified by PCR using oligonucleotide primers derived from the DR sequence (DRa:5'-GGT TTT GGG TCT GAC GAC-3' and DRb:5'-CCG AGA GGG GAC,GGA AAC-3'). A total volume of $25 \mu \mathrm{l}$ of the following reaction mixture was used for the PCR: $12.5 \mu \mathrm{l}$ of HotStarTaq master mix (Qiagen). This solution provides a final concentration of: $1.5 \mu \mathrm{M} \mathrm{MgCl} 2$ and $200 \mathrm{mM}$

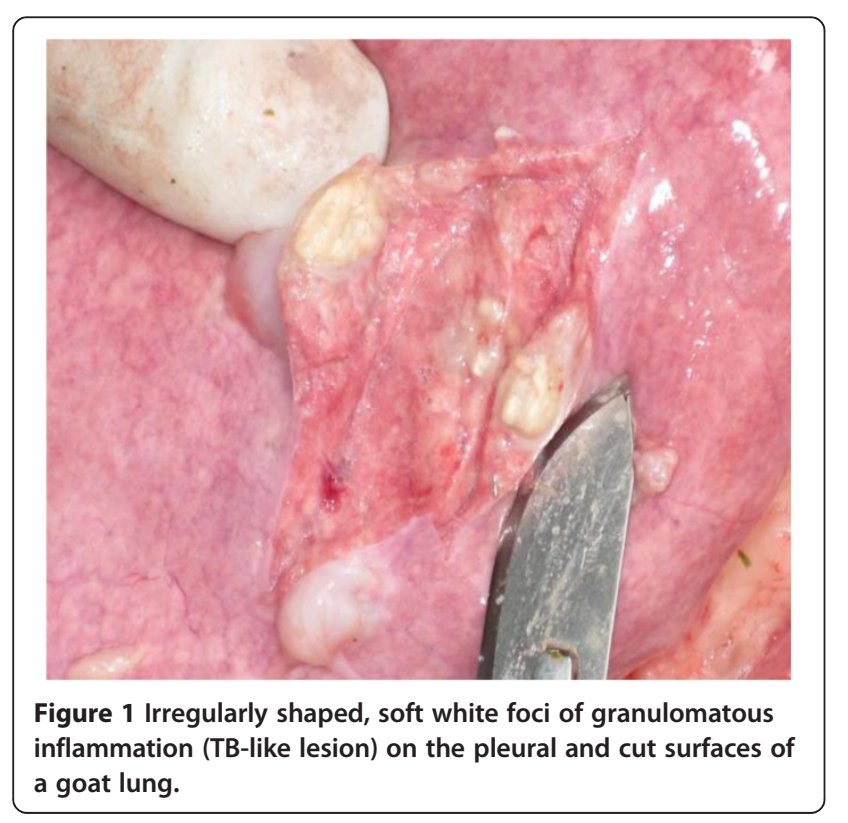

of each deoxynucleotides triphosphates, $2 \mu \mathrm{l}$ of each primer (20 p mol each), $5 \mu \mathrm{l}$ suspension of heat-killed cells (approximately 10 to $50 \mathrm{ng}$ ), and $3.5 \mu \mathrm{l}$ distilled water. PCR amplification was performed for $15 \mathrm{~min}$ at $96^{\circ} \mathrm{C}$ and then subjected to 30 cycles of $1 \mathrm{~min}$ at $96^{\circ} \mathrm{C} ; 1 \mathrm{~min}$ at $55^{\circ} \mathrm{C}, 30 \mathrm{sec}$ at $72^{\circ} \mathrm{C}$ and a final extension at $72^{\circ} \mathrm{C}$ for $10 \mathrm{~min}$.

The amplified products were hybridized to a set of 43 immobilized oligonucleotides, each corresponding to one of the unique spacer DNA sequences within the DR locus. After hybridization, the membrane was washed twice for $10 \mathrm{~min}$ in $2 \times \mathrm{SSPE}(1 \times \mathrm{SSPE}$ is $0.18 \mathrm{M} \mathrm{NaCl}, 10 \mu \mathrm{M}$ $\mathrm{NaH} 2 \mathrm{PO} 4$, and $1 \mu \mathrm{M}$ EDTA (pH 7.7) - 0.5\% sodium dodecyl sulfate at $60^{\circ} \mathrm{C}$ and then incubated in 1:4,000 diluted streptavidin peroxidase (Boehringer, Ingelheim Germany) for 45 to $60 \mathrm{~min}$ at $42^{\circ} \mathrm{C}$. The membrane was washed twice for $10 \mathrm{~min}$ in $2 \times \mathrm{SSPE}-0.5 \%$ sodium dodecyl sulfates at $42^{\circ} \mathrm{C}$ and rinsed with $2 \times$ SSPE for $5 \mathrm{~min}$ at room temperature $20^{\circ} \mathrm{C}$ ). Hybridizing DNA (presence or absence of the unique spacers) were detected by the enhanced chemiluminescence method (Amersham, Buckinghamshire, England) and by exposure to X-ray film (Hyperfilm ECL, Amersham), which detects light signals and thereby produces a pattern which allows for typing of isolates as specified by the manufacturer.

\section{Data collection, management and analysis}

For each individual animal examined age, goat type and geographical origin were recorded on a data sheet. Presence or absence of TB-like lesions and affected tissue(s) were recorded in database based on Microsoft ${ }^{\circledR}$ Excel for Windows 2007.

Descriptive statistics was used to estimate prevalence of TB-like lesions across the individual factors and lesion frequency in different anatomical locations. Uni-and multivariate logistic regressions were used to investigate possible associations between the prevalence and the explanatory variables. $P$ value $<0.05$ and $95 \%$ confidence level were used 


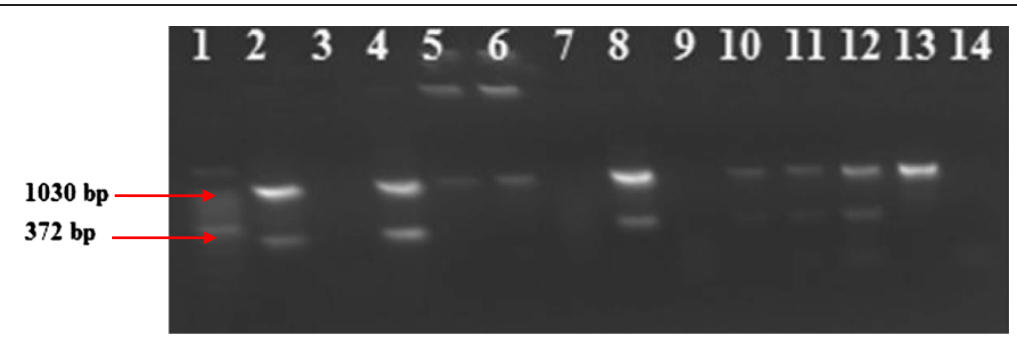

Figure 2 Gel Electrophoretic separation of PCR products by multiplex PCR genus typing of mycobacterial isolate from tuberculous tissue of goats. Lanes: $1=100$ bp DNA Ladder, $2=$ M. tuberculosis (positive control), $3=$ Qiagen H2O (negative control), 4= M. bovis, $5=M$. avium complex (positive control) and $6=M$. intracellulare complex (positive control). Lanes $7-14$ were samples from individual goats with TB-like lesions. Lanes 8, 10,11,12,13 were positive for the Genus Mycobacterium Lanes 8 and 10-12 showed bands for M. tuberculosis complex (MTBC) and lane 13 was positive only for the Genus Mycobacterium while lanes 7, 9 and 14 were negative.

for statistical significance. Statistical analysis was carried out using SPSS version 18.0 (SPSS Inc. Chicago, IL, USA).

Our project was evaluated and approved by the Institional Review Board (IRB) of the Aklilu Lemma Institute of Pathobiology, Addis Ababa University. The Reference Number of the approval letter/Minutes is IRB/01/2011-12.

\section{Results}

Prevalence of TB-like lesions in goats and associated risk factors

The prevalence of TB-like lesions was 3.5\% (2.69-4.31\%). It was significantly higher in older goats $(>1.5$ year) than in younger goats $(P<0.05)$ but there was no statistically significant difference in lesion prevalence between the different goat types and origins $(P>0.05)$ (Tables 2 and 3$)$. The highest (4.9\%) and lowest (2.1\%) prevalences of caprine TB-like lesions were recorded in goats originated from Borena and Somali areas, respectively.

\section{Distribution of pathology}

Characteristic TB-like lesions (Figure 1) were observed in both lung and lymph nodes.

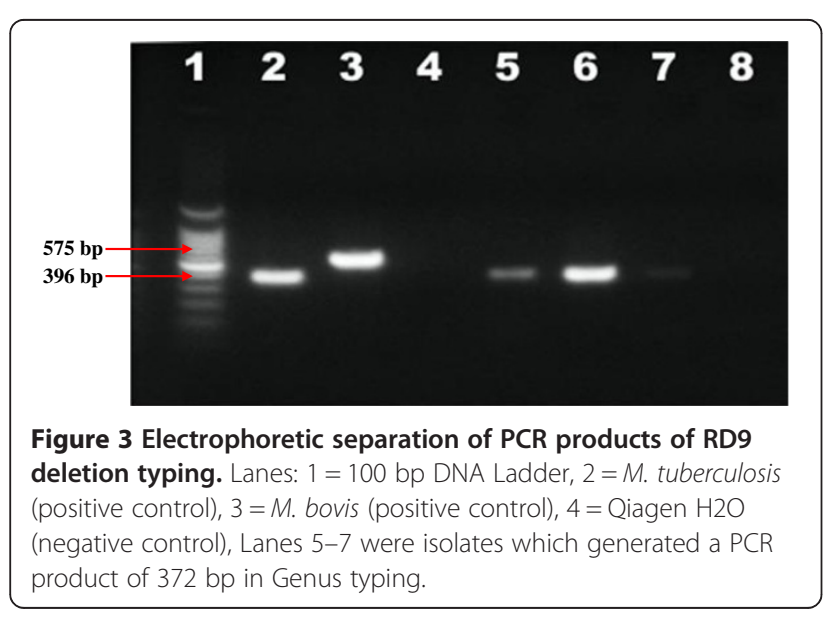

Most of the TB-like lesion were observed in the thoracic cavity (lung: $22 \%$ of cases, mediastinal lymph nodes: $42 \%$, and bronchial lymph nodes: $33 \%$ ) and only $3 \%$ was observed in mesenteric and hepatic lymph nodes.

\section{Culture and acid fast test microscopy results}

Seventy-eight samples from suspected TB lesions were processed and cultured. Bacterial growth was observed in $14 \%(11 / 78)$ of the sowed slants of which eight were confirmed to be acid fast bacilli (AFB).

\section{Genus identification of AFB isolates}

Genus typing revealed that five of the eight AFB positive isolates showed the expected PCR product (1030 bp) and could be identified as Mycobacterium species. Furthermore, four of these five isolates generated a PCR product of $372 \mathrm{bp}$ which belongs to MTBC group whereas the remaining isolate was considered to be atypical mycobacteria (Figure 2).

\section{RD9 deletion typing result}

To identify the species of the MTBC isolates, RD9 deletion typing was performed. In this deletion typing, all the three isolates generated a PCR product of $339 \mathrm{bp}$ confirming that they were M. tuberculosis (Figure 3) while one of the samples (Lane 8) did not produce the band (negative).

\section{Spoligotyping of $M$. tuberculosis isolates}

All the three isolates of M. tuberculosis showed distinct patterns indicating that they were different strains (Figure 4). One of these strains (SW6) was SIT53. However, the patterns of the remaining two strains (Ar3 and J18) were not recognized by the international spoliotyping database indicating that they were new strains.

\section{Discussion}

An abattoir-based epidemiological survey of caprine TB was conducted on goats originated from different regions of Ethiopia. Lesion-based prevalence was calculated and 


\begin{tabular}{|l|l|l|l|l|l|l|}
\hline ID & Species & Binary & Octal value & SIT & Family & Lineage \\
\hline H37Rv & Mtb & 111111111111111111001111111111100001111111 & & & & \\
\hline $\begin{array}{l}\text { Qiagen } \\
\mathrm{H}_{2} \mathrm{O}\end{array}$ & & & & & & \\
\hline JL8 & Mtb & 1110000111111111111011000000000000110011111 & 703777540003171 & New & CAS & Unknown \\
\hline Sw6 & Mtb & 111111111111111111111111111111100001111111 & 777777777760771 & 53 & T1 & $\begin{array}{l}\text { Euro- } \\
\text { American }\end{array}$ \\
\hline Ar3 & & 1111111111111011111111111111011100001111111 & 777757777560771 & New & T1 & $\begin{array}{l}\text { Euro- } \\
\text { American }\end{array}$ \\
\hline
\end{tabular}

Figure 4 Spoligotype patterns of $\boldsymbol{M}$. tuberculosis isolates from goats. One of the goat isolate was SIT53 while the other two were new to the Spoligotype International Typing (SITVIT) Database. The octal numbers of the two new strains are 703777540003171 and 777757777560771.

mycobacteria were characterized. Compared to the two previous studies carried out on goat TB in Ethiopia, this study was more comprehensive as the number of goats included was relatively higher, the origin and types of animals was more representatives of the reference population and advanced molecular techniques were used.

The overall lesion prevalence of $3.5 \%$ reported in this study is similar to the prevalence reported in previous studies in Ethiopia. A TB-like lesion prevalence of $4.2 \%$ in 1,536 goats was reported in a study conducted in 2005 at Modjo Modem Export Abattoir [18]. A similar prevalence (4.3\% in 1,152 goats) was recorded based on gross lesions at Helmex Export Abattoir [10]. Likewise, a prevalence of $3.1 \%$ in 193 goats was reported in goats kept at Adami Tulu Research Center using a single intradermal tuberculin test (TST) [29]. Studies conducted in other countries have also reported similar results $[3,30]$.

A significantly higher prevalence of TB-like lesions in goats aged $>1.5$ years is in agreement with a study [30], which reported higher prevalence in older goats although the goats were older than 6 years in that study. Similarly, several cross sectional studies conducted on bovine TB have reported higher prevalences of $\mathrm{TB}$ in older cattle $[11,14,31]$. This may be explained by an age depend risk of exposure.

The prevalences of TB in goats that originated from the different zones and regions were similar indicating the overall similarity of management system and infection pressure. This finding is consistent with that of an earlier study [6], which reported similar prevalences in different regions of Ethiopia. A significantly higher prevalence was recorded for goats originating from the Borena area as compared to those from Somali region although the goats types were the same in both areas.

The present study showed that TB-like lesions were almost exclusively observed in the thoracic cavity of goats. A similar study has shown that $97 \%$ of the gross TB-like lesions were found in the lungs and associated lymph nodes [18], while lesions were only found in the thoracic cavity in Algerian goats [6]. This indicates that goats acquire the infection mainly through the respiratory route [32].

The isolation of three M. tuberculosis strains was unexpected as a previous study has reported that the causative agent of caprine TB in some European countries was $M$. bovis $[9,11]$ and $M$. caprae in several European countries [33]. Even recently, outbreaks of TB in goats in the United Kingdom, Italy and Portugal were reported to be caused by $M$. bovis $[2,5,34]$. However, $M$. tuberculosis has previously been isolated from goats in Nigeria [3]. The isolation of $M$. tuberculosis from goats in this study is likely to be due to transmission of the bacterium from TB infected people to goats as has been suggested earlier [11]. Transmission of $M$. tuberculosis from man to cattle has been reported from Slovenia [35] and in Ethiopia; cattle owned by farmers with active TB were four times more likely to have TB than cattle owned by those farmers without active TB [7].

\section{Conclusion}

This study documented an equal low prevalence of caprine TB-like lesions across a range of eco-epidemiological settings in Ethiopia. The high prevalence of lesions in the lung and associated lymph nodes suggests that transmission of TB to goats is mainly through the respiratory route. The isolation of the SIT53 strain of M. tuberculosis from goats in this study suggests transmission from humans.

\section{Competing interests}

We have no financial or other competing interests to declare in relation to this manuscript.

\section{Authors' contributions}

The study was conceived and designed by BD, GA and FJC. Field work was performed by BD; Laboratory work was done by BD and GA. Analysis of data and preparation of the manuscript was a joint contribution of BD, FJC and GA. All authors read and approved the final version of the manuscript.

\section{Acknowledgments}

The study was financially supported by Ethiopian Ministry of Agriculture, Aklilu Lemma Institute of Pathobiology and EDUlink.

\section{Author details}

'Aklilu Lemma Institute of Pathobiology, Addis Ababa University, PO Box 1176, Addis, Ethiopia. ${ }^{2}$ Jimma University College of Agriculture and Veterinary Medicine, PO Box 307, Jimma, Ethiopia. ${ }^{3}$ Friedrich-Loeffler Institute of Epidemiology, Seestraße 5516868, Wusterhausen, Germany. ${ }^{4}$ Freie Universität Berlin, Koenigsweg 67, 14163, Berlin, Germany.

Received: 12 May 2012 Accepted: 15 February 2013

Published: 21 February 2013 


\section{References}

1. Aranaz A, Liebana E, Gomez-Mampaso E, Galan JC, Cousins D, Ortega A, Blazquez J, Baquero F, Mateos A, Suarez G, Dominguez L: Mycobacterium tuberculosis subsp. caprae subsp. nov: A taxonomic study of a new member of the Mycobacterium tuberculosis complex isolated from goats in Spain. Int J Sys Bacteriol 1999, 49:1263-1273.

2. Daniel R, Evans H, Rolfe S: Outbreak of tuberculosis caused by Mycobacterium bovis in golden Guernsey goats in Great Britain. Vet Rec 2009, 165:335-342.

3. Cadamus S, Adesokan H, Jenkins A, Van Solingen D: Mycobacterium tuberculosis and M. bovis in goats, Nigeria. Em Inf Dis 2009, 15:2066-2069.

4. Hiko A, Agga GE: First-time detection of mycobacterium species from goats in Ethiopia. Trop Anim Hlth Prod 2010, 43:133-139.

5. Tafess K, Dawo F, Sori T, Ameni G: Prevalence of caprine tuberculosis in Mid-Rift Valley area of Oromia, Ethiopia. Afr J Microbio Res 2011, 5:1473-1478.

6. Naima S, Borna M, Bakir M, Djamel Y, Fadila B, Jacob Z, Djamel G: Tuberculosis in cattle and goats in the North of Algeria. Vet Res 2011, 4:100-103.

7. Regassa $A$, Medhin $G$, Ameni $\mathrm{G}$ : Bovine tuberculosis is more prevalent in cattle owned by farmers with active tuberculosis in central Ethiopia. Vet J 2008, 178:119-125.

8. Sharpe AE, Brady CP, Johnson AJ, Byrne W, Kenny K, Costello E: Concurrent outbreak of tuberculosis and caseous lymphadenitis in a goat herd. Vet Rec 2010, 166:591-592.

9. Prodinger WM, Brandstätter A, Naumann L, Pacciarini M, Kubica T, Boschiroli ML, Aranaz A, Nagy G, Cvetnic Z, Ocepek M, Skrypnyk A, Erler W, Niemann S, Pavlik I, Moser I: Characterization of Mycobacterium caprae isolates from Europe by mycobacterium interspersed repetitive unit genotyping. J Clin Microbiol 2005, 43:4984-4992

10. Nigussie T: Preliminary study of tuberculosis in small ruminants slaughtered at helimex export abattoir. Debre-Zeit, Ethiopia: DVM thesis Faculty of Veterinary Medicine; 2005.

11. O'Reilly LM, Daborn CJ: The epidemiology of Mycobacterium bovis infections in animals and man: a review. Tuber Lung Dis 1995, 76:1-46.

12. Ameni G, Desta F, Firdessa R: Molecular typing of Mycobacterium bovis isolated from tuberculosis lesions of cattle in north eastern Ethiopia. Vet Rec 2010, 167:138-141.

13. Hailemariam S: A brief analysis of activities of meat inspection and quarantine division. Addis Ababa, Ethiopia: Department of Veterinary Service, Ministry of Agriculture; 1975.

14. Ameni G, Aseffa A, Engers H, Young D, Gordon S, Hewinson G, Vordemieier M: High prevalence and increased severity of pathology of bovine tuberculosis in Holsteins compared to zebu breeds under field cattle husbandry in central Ethiopia. ClinVac Immunol 2007, 14:1356-1361.

15. Ameni G, Ragassa A, Kassa T, Medhin G: Survey on bovine tuberculosis and its public health implications to cattle raising families in Wolaita Soddo, Southern Ethiopia. Ethiop J. Anim Prod 2001, 1:55-62.

16. Berg S, Firdessa R, Habtamu M, Gadisa E, Mengistu A, Yamuah L, Ameni G, Vordermeier M, Robertson BD, Smith NH, Engers H, Young D, Hewinson RG, Aseffa A, Gordon SV: The burden of mycobacterial disease in Ethiopian cattle: implication for public health. PLoS One 2009, 4:e5068-e5070.

17. Tsegaye W, Aseffa A, Machec A, Mengist Y, Bergd S, Ameni G: Conventional and molecular epidemiology of bovine tuberculosis in dairy farms in Addis Ababa City, the capital of Ethiopia. Int J Appl Res Vet Med 2010, 8:143-151.

18. International Livestock Research Institute (ILRI): Goat types of Ethiopia and Eritrea: physical description and management system. Nairobi, Kenya: FARMAfrica; 1996

19. Steele M: Goats. In Tropical Agriculturist and Technical Center for Agricultural and Rural Co-operation. London: Macmillan education Ltd; 1996:120-125.

20. Thrusfield M: Survey. In Veterinary Epidemiology. Blackwell Science Ltd: 2005:228-242.

21. Corner LA: Post-mortem diagnosis of Mycobacterium bovis infection in cattle. Vet Microbiol 1994, 40:53-63.

22. Asseged B, Woldesenbet Z, Yimer E, Lemma E: Evaluation of abattoir inspection for the diagnosis of $M$. bovis infection in cattle at Addis Ababa Abattoir. Trop Anim Hlth Prod 2004, 36:537-546.

23. Gracy JF: Meat Hygiene. London: Bailliere-Tindall; 1986.

24. OIE: Bovine tuberculosis. In Manual of Diagnostic Tests and Vaccines for Terrestrial Part 2, Section 2.3. Chapter 2.3.3: World Organization for Animal
Health; 2010. www.oie.int/international-standard. . ./terrestrial-manual/ access-online.

25. Mcllroy SG, Neill SD, McCracken RM: Pulmonary lesions and Mycobacterium. bovis excretion from the respiratory tract of tuberculin reacting cattle. Vet Rec 1986, 118:718-721.

26. Wilton S, Cousins D: Detection and identification of multiple mycobacterial pathogens by DNA amplification in a single tube. $P C R$ Methods Appl 1992, 1:269-273.

27. Gordon SV, Brosch R, Billaut T, Garnier K, Eiglmeier, Cole ST: Identification of variable regions in the genomes of tubercle bacilli using bacterial artificial chromosome arrays. Mol Microbiol 1999, 32:643-655.

28. Kamerbeek J, Schouls L, Kolk A, Van Agterveld M, Van Soolingen D, Kuijper S, Bunschoten A, Molhuizen H, Shaw R, Goyal M, Van Embden J: Simultaneous detection and strain differentiation of Mycobacterium tuberculosis for diagnosis and epidemiology. I Clin Microbiol 1997. 35:907-914

29. Crawshaw T, Daniel R, Clifton-Hadley R, Clark J, Evans H, Rolfe S, de la Rua Domenech R: TB in goats caused by Mycobacterium bovis. Vet Rec 2008, 163:127-132.

30. Javed MT, Ahmad L, Irfan M, Ali I, Khan A, Wasiq M, Farooqi FA, Latif MS, Cagiola M: Hematological and serum protein values in tuberculin reactor and non-reactor water buffaloes, cattle, sheep and goats. Pak Vet J 2010, 30:100-104

31. Biffa D, Inangolet F, Oloya J, Asseged B, Badaso M, Yilkal A, Skjerve E. Prevalence of bovine tuberculosis in Ethiopian slaughter cattle based on post-mortem examination. Trop Anim Hlth Prod 2009, 41:755-765.

32. Vordermeier HM, Chambers MA, Cockle PJ, Whelan AO, Simmons J, Hewinson RG: Correlation of ESAT-6-specific gamma interferon with pathology in cattle following Mycobacterium bovis BCG vaccination against experimental bovine tuberculosis. Infect Immunol 2002, 70:3026-3032.

33. Ayele WY, Neill SD, Zinsstag J, Pavlik I: Bovine tuberculosis: an old disease but a new threat to Africa. Int J Tub Lung Dis 2004, 8:924-937.

34. Quintas H, Reis J, Pires I, Alegria N: Tuberculosis in goats. Vet Rec 2010, 166:437-438.

35. Ocepek M, Pate M, Olnir-Dovc M, Poljak M: Transmission of Mycobacterium tuberculosis from human to cattle. J Clin Microbiol 2005, 43:3555-3557.

doi:10.1186/1751-0147-55-15

Cite this article as: Deresa et al: Abattoir-based study on the epidemiology of caprine tuberculosis in Ethiopia using conventional and molecular tools. Acta Veterinaria Scandinavica 2013 55:15.

\section{Submit your next manuscript to BioMed Central and take full advantage of:}

- Convenient online submission

- Thorough peer review

- No space constraints or color figure charges

- Immediate publication on acceptance

- Inclusion in PubMed, CAS, Scopus and Google Scholar

- Research which is freely available for redistribution 